\title{
DENTAL IMPLANT MATERIALS, IMPLANT DESIGN, AND ROLE OF FEA- A BRIEF REVIEW
}

\author{
Duraisamy Velmurugan ${ }^{1}$, Alphin Masilamani Santha², Sachin Gaurishankar Sarate ${ }^{3}$
}

${ }^{1}$ Research Scholar, Department of Mechanical Engineering, SSN College of Engineering, Kalavakkam, Chennai. ${ }^{2}$ Associate Professor, Department of Mechanical Engineering, SSN College of Engineering, Kalavakkam, Chennai. ${ }^{3}$ Doctor, Department of Biomedical Engineering, SSN College of Engineering, Kalavakkam, Chennai.

\section{ABSTRACT}

\section{BACKGROUND}

A dental implant is utilised to hold the counterfeit tooth into its legitimate position in the human jaw. It fills the need of characteristic root which is there in a normal tooth. Implant design, implant stability, materials used in dental implants are the main factors required for the long-haul accomplishment of a dental implant.

The aim of this article is to give a brief review on dental implant materials, implant design, numerical approach used in dental implants by the researchers over the years.

\section{KEYWORDS}

FEA, Implant Design, Implant Materials.

HOW TO CITE THIS ARTICLE: Velmurugan D, Santha AM, SarateSG.Dental implant materials, implant design, and role of FEA- A brief review.J. Evolution Med. Dent. Sci. 2017;6(44):3487-3492, DOI: 10.14260/Jemds/2017/753

\section{BACKGROUND}

Logical investigation of memorable confirmation demonstrates that people have tried to supplant missing teeth with root shape inserts for a great many years. [1] Four thousand years back in old China, for supplanting lost teeth, bamboo pegs were utilised. Bamboo pegs take advantage of the bone to supplant lost teeth. Valuable metals have been utilised as a part in old Egypt to make a likewise formed peg. In some Egyptian mummies, transplanted human teeth were found. These teeth were made of ivory.[2-3] Advancement of dental inserts achieved its new stature in the early part of the twentieth century. More implants were made of an assortment of materials. The Greenfield introduced the best implant arrangement in 1913.[4] Bothe, Beaton and Davenport utilised titanium as a first implantable material in 1940.[5] Bothe et al were the primary analysts to mark the name osseointegration. Osseointegration was promoted later on by Per-Ingvar Brånemark. The Achievement rate of osseointegration relies upon the material which is utilised for making an implant. Titanium poles were implanted in rabbits by Gottlieb Leventhal in 1951. The result of this persuaded titanium is the perfect material for surgery.[6] Present day dental implant turned into a critical use of choice in the substitution of harmed teeth or loss of characteristic teeth since 1960. The quantity of implant plans and number of implant businesses are accessible nowadays. At present implants are accessible with various distances across, lengths and diverse shapes and sizes. Implant outlines are accessible within thread frames and furthermore without thread shapes.[7]

Financial or Other, Competing Interest: None.

Submission 27-04-2017, Peer Review 21-05-2017,

Acceptance 27-05-2017, Published 01-06-2017.

Corresponding Author:

Alphin Masilamani Santha,

Associate Professor,

SSN College of Engineering,

Kalavakkam, Chennai-603110.

E-mail: alphin@aol.in

DOI: $10.14260 /$ jemds $/ 2017 / 753$

\section{(c) $($ ) $(-)$}

Biomechanical thought is utilised to decide the long haul achievement of the dental implant. It depends on the strengths they need to bolster.

The aftermath of concentrated constraint prompts to break of implant segments, or loss of bone neighbouring the implant. [8] Biologic components and mechanical elements assume an imperative part to find the inserts. Inserts have low disappointment rates when they are set in more grounded and thicker bone, for example base jaw, and have high disappointment rates when they are put in lower thickness bone, for example some portion of the upper jaw. The force on implants likewise increments when individuals granulate their teeth, this may prompt to a probability of disappointments. ${ }^{[9]}$

This article review the writing on materials utilised as a part of dental implant, dental implant design, and numerical approach utilised as a part of dental inserts.

\section{Implant Materials}

Brånemark (1960) introduced oral implants and it became a reliable treatment option for the replacement of missing teeth.[10] Dental implant material properties such as physical and chemical properties are well reported and documented. Properties of materials may contain the microstructure of the implant, its surface characteristics and design factors.[11] A perfect implant material must have biocompatibility, adequate strength, toughness, wear resistance and corrosion resistance.[11,12] Material which is used for the fabrication of dental implants are categorised according to their chemical composition and biological responses. The design principles of the implant should be compatible with physical properties of the dental implant material.[13] Metals, ceramics or polymers are some commonly used materials to make an implant in dentistry. Dental implants fall into any of the abovementioned group.

\section{Metals and Ceramics}

For dental implants, metals are selected based on a factor involved with its properties. These properties are belonging to its biomechanical characteristics, surface finishing characteristics and its machining characteristics. Metals like Co-Cr, stainless steel, gold are outdated in the dental implant industry. The currently available dental metals are Titanium 
and its alloys, Zirconium. But some of the dental implant components like abutment, abutment screws, and various attachments are made of gold alloys, $\mathrm{Co}-\mathrm{Cr}$ alloys and stainless steels. ${ }^{[14]}$

Titanium is the material of choice for intraosseous applications because it has typical properties like high passivity, resistance to chemical dose. Also, it has ability to repair itself if damaged. Its modulus of elasticity 116 GPais compatible with that of bone and titanium oxide.[15] However, titanium which is a typical material for dental implants has a few drawbacks. Titanium is unaesthetic in the frontal area.[16] Ti-6Al-4V, Ti-6Al-4V extra low interstitial are commonly used materials. These detriments of titanium prompted to new implant innovation.

Ceramic implants are being developed to overcome the above said drawbacks.[17] As a result of this zirconia is used as another material for dental inserts. Contrasted with metallic components zirconia demonstrates least particle discharge and they are thought to be dormant in the body.[18] Zirconia has a tooth like shading, great mechanical properties and subsequently great biocompatibility. In this way it is by all accounts an appropriate dental material.[19] The utilisation of zirconia inserts maintains a strategic distance from this inconvenience and acquiesces to the demand of numerous patients for without metal inserts. The material additionally gives high quality, crack sturdiness, and biocompatibility. ${ }^{[20]}$ Table 1 indicates materials used for fabricating endosseous dental implants.[21-23]

\section{Polymers}

A variety of polymers have been utilised as dental implant materials.[24] A portion of the polymer materials are polymethylmethacrylate, polytetrafluoroethylene, polyethylene, polysulfone, polyurethane. When polymer acts as coating layer, inferior mechanical properties, lack of adhesion to living tissues, and adverse immunologic reactions are eliminated.[24-28] Today, polymeric materials are constrained to the assembling of shock retaining segments joined into the superstructures bolstered by inserts.[29]

An extensive variety of biomaterials are as of now being used for inserts. It gets to be distinctly important to choose adept biomaterial. Proper determination of biomaterials straightforwardly impacts clinical achievement and life span of inserts. The current materials like bioceramics and composite biomaterials which are under thought and examination have a promising future.

\section{Implant Design}

Implant configuration refers to the three-dimensional structure of the implant. To depict the three-dimensional structure frames, shape, setup, surface, full scale structures and large scale anomalies have been utilised. Success rate of implant depends on two factors, namely implant design and surface conditions. Although implants have been used for close to a half century with incredible accomplishment, there are couple of rules that depict when or where to utilise the distinctive sorts of inserts. Comprehension and utilising biomechanical hypotheses that influence endosseous implant configuration may enhance the accomplishment of these inserts in different load conditions and may permit the clinician to better apply these rules, with a change in achievement rates. Many interrelated components are included for outlining dental inserts. A portion of the elements are geometry of the implant, mechanical properties and long-haul steadiness. There is no standard design to measure the ability of the dental implant to exchange load to encompassing biologic tissues.[30] Along these lines the essential plan goal is to oversee biomechanical load. Different design of implant leads to show variation in stress distribution. The figure 1 shows variation of stress against different sizes of pitch.

Dental Implant configuration can be ordered under the accompanying headings: Implant design classification, Plan and creation of Redid Dental Inserts and effect of thread pattern. Large scale outline and small scale configuration are two central points contributed for implant plans known as macro and microdesign respectively. Thread pattern and thread design goes under macrodesign. Materials for inserts, surface morphology and surface coating are a portion of the variables centred under microdesign.[31] This part of the review attempts to integrate information in dental implant designsuch as selection of implant diameter, length and shape of the implants.

\section{Implant Diameter}

Implant diameter is the measurement measured from the peak of the largest thread to a similar point on the inverse side of the implant. The outside dimension of the thread is measured by diameter. Since an assortment of implant widths and stages are accessible, a wide-stage implant is not generally unplanned with an expanded diameter of the implant thread. As of now implants vary in diameter from 3 to $7 \mathrm{~mm}$. The necessities for implant diameter depend on both surgical and prosthetic prerequisites. Width of implant is designed to gain maximum stability. From a biomechanical point of view utilisation of wider implants permits engagement of a maximal measure of bone, and distribution of stress is improved theoretically.[32] Distribution of the stress depends on diameter of the implant. Distribution of stress varies with respect to implant design. The figure 2 shows variation of stress against different designs of implant.

\section{Implant Length}

It is the length from the platform to the peak of implant. Length of the implant was delegated short, medium and long. The scope of short implant length was from 6-9 $\mathrm{mm}$. The medium implant length lies between $10-12 \mathrm{~mm}$ and long implant length ranges from 13-18 $\mathrm{mm}$. In spite of the fact that a direct connection amongst length and achievement rate has not been confirmed, the studies show that shorter inserts have literally brought down achievement rates.[33] The $7 \mathrm{~mm}$ implant length prompts to more dissatisfaction rate while comparing with other implant lengths. ${ }^{[34]}$ An investigation of fixed single-unit rebuilding efforts showed that a connection between implant length and achievement may not exist, particularly more than $13 \mathrm{~mm}$ in length. ${ }^{[35]}$ No connection between introductory versatility and implant length has been established[36] and mechanical examinations have bolstered the view that expanding the implant length may just build achievement rate to a specific extent.[37] 


\section{Implant Shape}

The states of dental inserts have changed from customary root structures to sharp edge and subperiosteal designs.[38] The state of dental inserts has been a standout amongst the most challenged parts of outline among the endosseous frameworks and may affect implant biomechanics.[39] Most current implant frameworks are accessible as strong or hollow screws or cylinders. Some implant manufacturers give implants in both shapes and suggest their utilisation in various sorts of bone. Among screw shaped implants, extensive modification has been made to the crestal and apical bit of the implant to expand self-tapping. Different outlines have been created to impersonate root life structures and consolidate a ventured round and hollow plan, comparable to the tooth root at both cervical and apical finishes. These stepped cylindrical implants demonstrate more even stress dispersal contrasted with tube shaped or decreased implants.[40]

\section{Numerical Approach Used in Dental Implants}

Finite Element Analysis (FEA) has turned into an undeniably valuable tool for the estimate of the impacts of stress on the implant. The loads from vertical and transverse direction leads to axial force and bending moments and result of this stresses are induced in implants. A key component for the achievement or disappointment of a dental implant is the way in which stresses are exchanged to the encompassing bone. The researchers used FEA to know how the stresses are distributed in the implants.

\section{Role of FEA in Biomechanical System}

For issues including convoluted geometries, it is exceptionally hard to accomplish an exact solution. In this way, the utilisation of numerical techniques, for example, FEA is required. FEA is a strategy for getting an answer for a complex mechanical issue by separating the issue area into an accumulation of considerably littler and less complex areas. Since the parts in a dental implant bone framework are greatly unpredictable geometrically, FEA has been seen as the most appropriate device for examining them. The advancement of FEA began in the mid-1960s to solve problems associated with aerospace industry. However, application of FEA stretched out to solve heat transfer problems, fluid stream. The use of FEA in implant dentistry began in 1976.[41] Stress distribution is performed in an implant which has a place with single tooth to know the impact of parameters and geometry of the implant.[42-44] 3D investigation of FEA performed by Borchers and Reichart.[45] The foremost trouble in recreating the mechanical conduct of dental inserts is the displaying of human bone tissue and its reaction to connected mechanical device. Certain suspicions should be made to make the displaying and understanding procedure conceivable. The unpredictability of the mechanical portrayal of bone and its collaboration with implant frameworks has constrained creators to make significant disentanglements. A few suspicions impact the precision of the FEA comes about essentially. These include: (1) itemised geometry of the bone and implant to be modeled, (2) material properties, (3) limit conditions ${ }^{[46]}$ and (4) the interface amongst bone and implant.[47] Table 2 indicates summary of literature used in FEA.

Material properties enormously impact the anxiety conveyance in a structure. In most announced reviews, the assumption is made that the materials are homogeneous and linear and that they have flexible material conduct described by two material constants of Young's modulus and Poisson's proportion. The design methodology includes complete factors like threads nature on surface of the implant and different bone properties. ${ }^{[48]}$ Most FEA studies demonstrating the mandible set the limit conditions as settled. The utilisation of interminable components can be a decent approach to model limit conditions.

In outline, stress dispersion relies on upon assumptions made in demonstrating geometry, material properties, limit conditions, and the bone-implant interface. To get more exact stress value, progressed computerised imaging procedures can be connected to demonstrate the bone geometry all the more practically; the anisotropic and non-homogenous nature of the material must be considered; and limit conditions must be precisely treated with the utilisation of computational displaying methods.

\begin{tabular}{|c|c|}
\hline Implant Material & Common Name \\
\hline \multicolumn{2}{|c|}{ I. Metals } \\
\hline Titanium & cpTi \\
\hline Titanium Alloy & Ti6Al4V \\
\hline Stainless steel & SS, 316 L SS \\
\hline Co-Cr Alloy & Vitallium, Co-Cr-Mo \\
\hline Cold Alloys & \\
\hline Tantalum & $\mathrm{Ta}$ \\
\hline \multicolumn{2}{|c|}{ II. Ceramics } \\
\hline Alumina & $\begin{array}{l}\mathrm{Al}_{2} \mathrm{O}_{3} \text {, amorphous or single } \\
\text { crystal sapphire (Kyocera) }\end{array}$ \\
\hline Hydroxyapatite & $\mathrm{HA}, \mathrm{Ca}_{10}\left(\mathrm{PO}_{4}\right)_{10}(\mathrm{OH})_{2}$ \\
\hline Beta-Tricalcium Phosphate & $\mathrm{B}-\mathrm{TCP} \mathrm{Ca}_{3}\left(\mathrm{PO}_{4}\right)_{2}$ \\
\hline Carbon & $\begin{array}{l}\text { Vitreous, low temperature } \\
\text { isotropic (LTI), ultra-low } \\
\text { temperature isotropic (ULTI) }\end{array}$ \\
\hline Carbon -silicon & $\mathrm{C}-\mathrm{Si}$ \\
\hline Bio-glass & $\mathrm{SiO}_{2} / \mathrm{CaO} / \mathrm{Na}_{2} \mathrm{O} / \mathrm{P}_{2} \mathrm{O}_{5}$ \\
\hline \multicolumn{2}{|c|}{ III. Polymers } \\
\hline Polymethylmethacrylate & PMMA \\
\hline Polytetrafluoroethylene & PTFE \\
\hline Polyethylene & $\mathrm{PE}$ \\
\hline Polysulfone & PSF \\
\hline Polyurethane & PU \\
\hline \multicolumn{2}{|c|}{ Table 1. Materials used in Dental Implants } \\
\hline
\end{tabular}




\begin{tabular}{|c|c|c|c|}
\hline Author & Objectives & Material and Methods & Conclusions \\
\hline Weinstein AM et al 1975 & $\begin{array}{c}\text { The distribution of stress and } \\
\text { magnitude was investigated }\end{array}$ & $\begin{array}{c}\text { Porous rooted Co-Cr-Mo alloy Dental } \\
\text { Implants. } \\
17 \mathrm{~mm} \text { long and } 5.5 \mathrm{~mm} \text { diameter }\end{array}$ & $\begin{array}{l}\text { High concentration of stresses } \\
\text { occurs at the lower end of the } \\
\text { implant }\end{array}$ \\
\hline Atmaram GH et al 1979 & $\begin{array}{c}\text { Stress distribution within and } \\
\text { around the implants were } \\
\text { determined. }\end{array}$ & $\begin{array}{c}\text {-5 different materials (dentin, } \\
\text { vitallium, titanium, vitreous carbon } \\
\text { and polymethyl methacrylate (PMMA) } \\
\text { - } 3 \text { different implant geometry } \\
\text { (Conical, Natural tooth root implant, } \\
\text { Cylindrical implant) } \\
\text { - Ankylosed single-tooth implants } \\
\text { were used. }\end{array}$ & $\begin{array}{c}\text {-Most favourable stress } \\
\text { distributions at cylindrical } \\
\text { implant. } \\
\text {-High reduction of stresses is } \\
\text { possible while using non-biologic } \\
\text { material. }\end{array}$ \\
\hline Atmaram GH et al 1979 & $\begin{array}{l}\text { Biomechanical design of } \\
\text { cylindrical implant was } \\
\text { optimised }\end{array}$ & $\begin{array}{l}\text {-Cylindrical root geometry implant. } \\
\text {-FEA method used. }\end{array}$ & $\begin{array}{l}\text { Significant reduction in high } \\
\text { alveolar stress while providing } \\
\text { longer length for cylindrical } \\
\text { implants. }\end{array}$ \\
\hline S.D. Cook et al 1982 & $\begin{array}{l}\text { To develop a } \\
\text { Finite element computer } \\
\text { model for porous rooted } \\
\text { dental implants. }\end{array}$ & $\begin{array}{l}\text {-Cylindrical design implant } \\
\text {-Co-Cr-Mo alloy used }\end{array}$ & $\begin{array}{l}\text { Direct bone-to-implant interface } \\
\text { may not be a good representation } \\
\text { for a porous rooted implant }\end{array}$ \\
\hline Borchers L et al 1983 & \begin{tabular}{|c|}
$\begin{array}{c}\text { The distribution of stress in } \\
\text { the bone surrounding implant } \\
\text { was determined. }\end{array}$ \\
\end{tabular} & $\begin{array}{l}\text {-Anchor type endosteal implant } \\
\text {-Ceramic }\left(\mathrm{Al}_{2} \mathrm{O}_{3}\right)\end{array}$ & $\begin{array}{l}\text { Crestal region of the alveolar bone, } \\
\text { High stress peaks were calculated }\end{array}$ \\
\hline Reinhardt RA et al 1984 & $\begin{array}{c}\text { Principal periodontal } \\
\text { ligament stresses in primary } \\
\text { and Secondary occlusal } \\
\text { trauma was calculated. }\end{array}$ & $\begin{array}{c}\text { Labiolingual cross sectional } \\
\text { model of the tooth, periodontal } \\
\text { ligament, gingiva, and alveolar bone } \\
\text { was developed }\end{array}$ & $\begin{array}{c}\text { Areas of greatest compressive } \\
\text { stress near the } \\
\text { Alveolar crest }\end{array}$ \\
\hline Maeda Y et al 1989 & $\begin{array}{l}\text { To evaluate the relative } \\
\text { effects of rebasing and the } \\
\text { position of occlusal loading } \\
\text { on the compressive strains }\end{array}$ & $\begin{array}{l}\text { A 2D plane-stress finite-element } \\
\text { simulation } \\
\text { model was used. }\end{array}$ & $\begin{array}{l}\text { A complete denture is related to } \\
\text { compressive stresses transmitted } \\
\text { to the bone. }\end{array}$ \\
\hline Rieger MR, et al 1990 & $\begin{array}{l}\text { Stress magnitudes and } \\
\text { contours in the bone } \\
\text { surrounding were } \\
\text { determined. }\end{array}$ & $\begin{array}{l}\text { Six post-type endosseous implants } \\
\text { were selected. }\end{array}$ & $\begin{array}{l}\text {-Denar implants leads to higher } \\
\text { stresses } \\
\text { - The Miter and RBT } 411 \text { implants } \\
\text { had good bone stress distribution. }\end{array}$ \\
\hline Akpinar I et al 1996 & $\begin{array}{c}\begin{array}{c}\text { Displacement of nature teeth } \\
\text { was investigated }\end{array} \\
\end{array}$ & $\begin{array}{c}\text {-Two-rigid implant (hollow and solid } \\
\text { screw)design used }\end{array}$ & $\begin{array}{l}\text {-Solid screw implant is more } \\
\text { suitable. }\end{array}$ \\
\hline $\begin{array}{c}\text { Van Oosterwyck H et al } \\
1998\end{array}$ & $\begin{array}{l}\text { Stress, strain distribution } \\
\text { around an implant were } \\
\text { studied }\end{array}$ & $\begin{array}{c}\text {-Solitary Brånemark } \\
\text {-Cylindrical volume implant used }\end{array}$ & $\begin{array}{l}\text {-Bone loading patterns are highly } \\
\text { sensitive. } \\
\text {-For FE models of the human jaw } \\
\text { stresses are important. }\end{array}$ \\
\hline Bulent Ekici 2002 & $\begin{array}{c}\text { Effect of washer in implant on } \\
\text { the loosening condition was } \\
\text { determined. }\end{array}$ & $\begin{array}{l}\text { 3D model of standard Brånemark } \\
\text { single implant system was used. }\end{array}$ & $\begin{array}{l}\text { Washer has an important effect } \\
\text { against loosening. Washer does } \\
\text { not affect the application of } \\
\text { preload. }\end{array}$ \\
\hline $\begin{array}{l}\text { Canan Hekimoglu et al } \\
\qquad 2004\end{array}$ & $\begin{array}{l}\text { To compare strains induced } \\
\text { around a natural tooth } \\
\text { opposing an implant with } \\
\text { strains around occluding } \\
\text { implants under static and } \\
\text { dynamic loads. }\end{array}$ & $\begin{array}{c}\text { Nobel Biocare, } 5 \mathrm{~mm} \text { diameter and } 13 \\
\mathrm{~mm} \text { length was used. }\end{array}$ & $\begin{array}{l}\text { Under static and dynamic loads, } \\
\text { strain magnitudes around a } \\
\text { natural tooth were significantly } \\
\text { lower than that of an opposing } \\
\text { implant and occluding implants in } \\
\text { the contralateral side. }\end{array}$ \\
\hline Barıs, Simsek et al 2005 & $\begin{array}{l}\text { To evaluate the effects of } \\
\text { different inter-implant } \\
\text { distances on stress } \\
\text { distribution in the bone } \\
\text { around the } \\
\text { endosseous titanium } \\
\text { implants }\end{array}$ & ITI implant system was used & $\begin{array}{l}\text { The } 1.0 \mathrm{~cm} \text { of inter-implant } \\
\text { distance is the optimum distance } \\
\text { for two fixture implantation }\end{array}$ \\
\hline
\end{tabular}




\begin{tabular}{|c|c|c|c|}
\hline $\begin{array}{c}\text { Oguz Kayabası a et al } \\
2006\end{array}$ & $\begin{array}{c}\text { Static dynamic and fatigue } \\
\text { behaviours of the implant are } \\
\text { Investigated. }\end{array}$ & $\begin{array}{c}\text { The maximum stress values did } \\
\text { not reach the yield strength of } \\
\text { diameter and } 12 \mathrm{~mm} \text { long } \\
\text { abutment and prosthetic screws of } \\
\text { the Implant and it seems that the } \\
\text { implant is durable in all } \\
\text { conditions, static and dynamic } \\
\text { loading }\end{array}$ \\
\hline $\begin{array}{c}\text { Chih-Ling Chang et al } \\
2012\end{array}$ & Redesign of the implant. & $\begin{array}{c}\text { Implant was designed using topology } \\
\text { optimisation method. }\end{array}$ & $\begin{array}{c}\text { The new implant was shaped by } \\
\text { topology optimisation and } \\
\text { decreased the volume of the } \\
\text { traditional implant by } \\
\text { approximately } \\
17.9 \%\end{array}$ \\
\hline \multicolumn{2}{|r|}{}
\end{tabular}

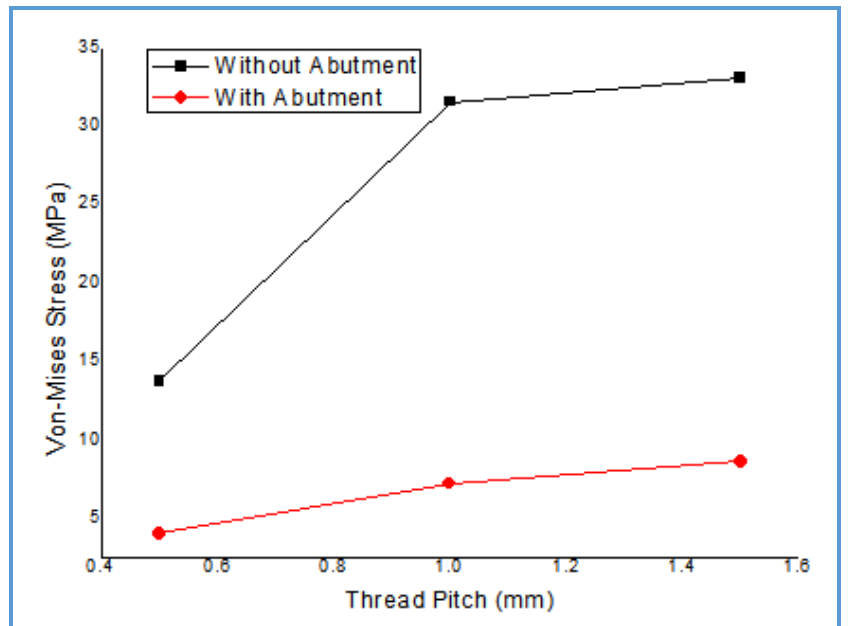

Figure 1. Maximum stress on the bone element of different pitch

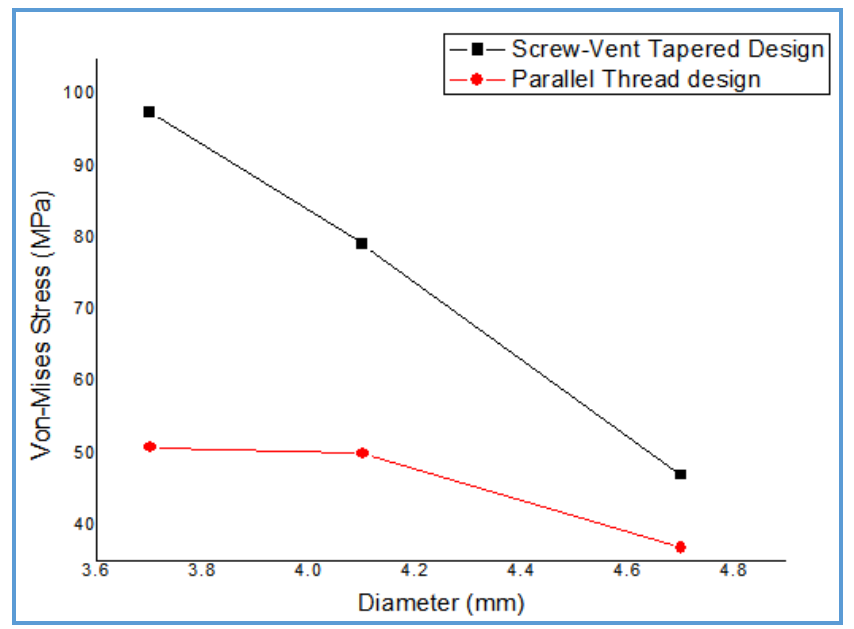

Figure 2. Von-Mises stress in implant design based on diameter.

\section{CONCLUSION}

This paper briefly reviews the materials used in dental implant, dental implant design, and numerical approach used in dental implants, dental implant stability. For an optimum implant design, biological, mechanical, physical properties should be considered. Since number of implant designs are available nowadays, operators should select current implant design based on the requirements. In numerical approach point of view, FEA has been used effectively to predict the biomechanical characteristics of any dental implant system. FEA is a powerful computational device that has been adjusted from the designing field to dental implant biomechanics.

\section{REFERENCES}

[1] Carl ME. Contemporary implant dentistry. $3^{\text {rd }}$ edn. St. Louis, Missouri: Mosby Elsevier 2007.

[2] Balaji SM. Textbook of oral and maxillofacial surgery. $2^{\text {nd }}$ edn. New Delhi: Elsevier India 200:301-02.

[3] Kenneth AJ. Phillips science of dental materials. 11 th edn. St. Louis, Missouri: Saunders Elsevier 2003; p. 6.

[4] Greenfield EJ. Implantation of artificial crown and bridge abutments. Dental Cosmos 1913;55(4):364-9.

[5] Bothe RT, Beaton LE, Davenport HA. Reaction of bone to multiple metallic implants. SurgGynecol Obstet 1940;71:598-602.

[6] LeventhalGS, Titanium, a metal for surgery. J Bone Joint Surg Am 1951;33-A(2):473-4.

[7] Noorthoek DR. Macroscopic and microscopic dental implant design: a review of the literature. MS thesis, Graduate School of the University of Florida, 2013.

[8] Patrick P. Optimal implant positioning and soft tissue management for the Branemark system (in English). Germany: Quintessence Books 1995:21-33.

[9] Per-Ingvar B.Zarb GA. Tissue-integrated prostheses (in English). Berlin, German: Quintessence Books1989.

[10] Brånemark PI, Hansson BO,Adell R,et al. Osseointegrated implants in the treatment of the edentulous jaw. Experience from a 10-year period. Scand J PlastReconstrSurgSuppl1977;16:1-132.

[11] Smith DC. Dental implants: materials and design considerations. IntJProsthodont 1993;6(2):106-17.

[12] Parr GR, GardnerLK,TothRW. Titanium: the mystery metal of implant dentistry. Dental materials aspect. J Prosthet Dent 1985;54(3):410-4.

[13] Sykaras N,Lacopino AM, Marker VA,et al. Implant materials, designs and surface topographies: their effect on osseointegration. A literature review. Int J Oral Maxillofac Implants 2000;15(5):675-90.

[14] Ravnholt G. Corrosion current and $\mathrm{pH}$ rise around titanium coupled to dental alloys. Scand J Dent Res 1988;96(5):466-72. 
[15] Kasemo B, Lausmaa J. Metal selection and surface characteristics. In: Brånemark P-I, Zarb GA, Albrektsson T. eds. Tissue-Integrated prostheses: osseointegration in clinical dentistry. Chicago: Quintessence 1985:99-116.

[16] Heydecke G, Kohal R, Gläser R. Optimal esthetics in single-tooth replacement with the Re-Implant system: a case report. Int J Prosthodont 1999;12 (2):184-9.

[17] Kohal RJ, Klaus G. A zirconia implant-crown system: a case report. Int J Periodontics Restorative Dent 2004;24(2):147-53.

[18] Sennerby L, Dasmah A, Larsson B, et al. Bone tissue responses to surface-modified zirconia implants: a histomorphometric and removal torque study in the rabbit. Clin Implant Dent Relat Res 2005;7(Suppl 1):S13-S20.

[19] Depprich R, Zipprich H, Ommerborn M, et al. Osseointegration of zirconia implants compared with titanium: an in vivo study. Head Face Med 2008;4:30.

[20] Piconi C, Maccauro G. Zirconia as a ceramic biomaterial. Biomaterials 1999;20(1):1-25.

[21] Williams DF. Implants in dental and maxillofacial surgery. Biomaterials 1981;2(3):133-46.

[22] Lemons JE. Dental implant biomaterials. J Am Dent Assoc 1990;121(6):716-9.

[23] Craig RG. Restorative dental materials. 9th edn. C.V. Mosby: St. Louis, MO, USA 1993; p. 169.

[24] Glantz PO. The choice of alloplastic materials for oral implants: does it really matter? Int J Prosthodont 1998;11(5):402-7.

[25] Carvalho TL, Araujo CA, TeofiloJM, et al. Histologic and histometric evaluation of rat alveolar wound healing around polyurethane resin implants. Int J Oral MaxillofacSurg 1997;26(2):149-52.

[26] Lemons JE. Dental implant biomaterials. J Am Dent Assoc 1990;121(6):716-9.

[27] Meijer GJ, StarmansFJ, de Putter C, van Blitterswijk CA. The influence of a flexible coating on the bone stress around dental implants. J Oral Rehabil 1995;22(2):105-11.

[28] Meijer GJ, Dalmeijer RA, de Putter C, et al. A comparative study of flexible (polyactive) versus rigid (hydroxyapatite) permucosal dental implants. II. Histological aspects. J Oral Rehabil 1997;24(2): 93-101.

[29] Meijer GJ, Heethaar J, Cune MS, et al. Flexible (polyactive) versus rigid (hydroxyapatite) dental implants. Int J Oral MaxillofacSurg 1997;26(2):135-40.

[30] Kawahara H. Cellular responses to implant materials: Biological, physical and chemical factors. Int Dent J 1983;33(4):350-75.

[31] Chapman RJ, Kirsch A. Variations in occlusal forces with a resilient internal implant shock absorber. Int J Oral Maxillofac Implants 1990;5(4):369-74.

[32] Misch CE. Density of bone: effect on treatment plans, surgical approach, healing, and progressive bone loading. Int J Oral Implantol 1990;6(2):23-31.
[33] Abuhussein H,Pagni G, Rebaudi A, et al. The effect of thread pattern upon implant osseointegration.Clin Oral Implant Res 2009;21(2):129-36.

[34] Ivanoff CJ, Sennerby L, Johansson C, et al. Influence of implant diameters on the integration of screw implants. An experimental study in rabbits. Int J Oral MaxillofacSurg 1997;26(2):141-8.

[35] Winkler S, Morris HF, Ochi S. Implant survival to 36 months as related to length and diameter. Ann Periodontol 2000;5(1):22-31.

[36] Wyatt CC, Zarb GA. Treatment outcomes of patients with implant supported fixed partial prostheses. Int J Oral Maxillofac Implants 1998;13(2):204-11.

[37] Eckert SE, Koka S, Wolfinger G, et al. Survey of implant experience by prosthodontists in the United States. J Prosthet Dent 2002;11(3):194-201.

[38] Douglass GL, MerrinRL. The immediate dental implant. J Calif Dent Assoc2002;30(5):362-5, 368-74.

[39] Lum LB. A biomechanical rationale for the use of short implants. J Oral Implantol 1991;17(2):126-31.

[40] Kurtzman GM, Schwartz K. The subperiosteal implant as a viable long term treatment modality in the severely atrophied mandible: a patient's 40 -year case history. J Oral Implantol 1995;21(1):35-9.

[41] Lin S, Shi S, LeGerosRZ, et al. Three-dimensional finite element analyses of four designs of a high-strength silicon nitride implant. Implant Dent 2000;9(1):53-60.

[42] Holmgren EP, Seckinger RJ, Kilgren LM, et al. Evaluating parameters of osseointegrated dental implants using finite element analysis-a two dimensional comparative study examining the effects of implant diameter, implant shape, and load direction. J Oral Implantol 1998;24(2):80-8.

[43] Weinstein AM, KlawitterJJ, Anand SC, et al. Stress analysis of porous rooted dental implants. J Dent Res 1976;55(5):772-7.

[44] AtmaramGH, Mohammed H. Stress analysis of singletooth implants. I. Effect of elastic parameters and geometry of implant. Implantologist 1983-84;3(1): 24-9.

[45] AtmaramGH, Mohammed H. Stress analysis of singletooth implants. II. Effect of implant root-length variation and pseudo periodontal ligament incorporation. Implantologist 1983-84;3:58-62.

[46] Mohammed H, AtmaramGH, Schoen FJ. Dental implant design: a critical review. J Oral Implantol 1979;8(3): 393-410.

[47] Borchers L, Reichart P. Three-dimensional stress distribution around a dental implant at different stages of interface development. J Dent Res 1983;62(2):155-9.

[48] Van Oosterwyck H, Duyck J, SlotenVJ, et al. The influence of bone mechanical properties and implant fixation upon bone loading around oral implants. Clin Oral Implants Res 1998;9(6):407-18. 